\title{
PEMODELAN MATEMATIKA DAN ANALISIS KESTABILAN MODEL PADA PENYEBARAN PENYAKIT CAMPAK DENGAN PENGARUH PROGRAM KESADARAN (Data Kasus Penyakit Campak Tahun 2017 di Kabupaten Kubu Raya)
}

\author{
Rimalia, Yundari, Yudhi
}

\section{INTISARI}

\begin{abstract}
Campak adalah suatu penyakit akut sangat menular yang disebabkan oleh virus. Penyakit ini ditandai dengan gejala awal demam, batuk, pilek dan konjungtivis yang kemudian diikuti dengan bercak kemerahan pada kulit (rash). Pada penelitian ini penyakit campak dimodelkan secara matematika berdasarkan asumsi dan pendefinisian parameter. Model matematika yang digunakan terdiri dari empat subpopulasi pada manusia yaitu subpopulasi rentan (S), subpopulasi terinfeksi (I), subpopulasi sembuh $(R)$ dan subpopulasi rentan yang sadar $\left(S_{m}\right)$. Selain itu, terdapat satu pengaruh pada proses penyebaran yaitu pengaruh program kesadaran (M). Model yang telah terbentuk, dicari determinan Routh-Hurwitz dan dianalisis untuk mengetahui perilaku dari sistem dengan menggunakan simulasi numerik. Simulasi model matematika dan nilai parameter menunjukkan bahwa terdapat dua titik kesetimbangan yaitu titik kesetimbangan bebas penyakit yang bersifat stabil asimtotik dan titik kesetimbangan endemik penyakit yang bersifat tidak stabil.
\end{abstract}

Kata kunci: model matematika, titik kesetimbangan, Routh-Hurwitz.

\section{PENDAHULUAN}

Model matematika merupakan representasi matematika yang dihasilkan dari pemodelan matematika. Pemodelan matematika merupakan suatu proses merepresentasikan dan menjelaskan permasalahan pada dunia nyata ke dalam pernyataan matematis, yang salah satunya yaitu tentang penyebaran penyakit campak. Campak adalah suatu penyakit akut yang disebabkan oleh virus. Gejala awal dari penyakit campak yaitu demam, batuk, pilek, konjungtivis dan bercak merah [1]. Berdasarkan data dari Dinas Kesehatan Provinsi Kalimantan Barat, terdapat 1.035 kasus campak pada tahun 2017 yang terdiri dari 14 kabupaten. Salah satu kabupaten yang mengalami peningkatan penyebaran penyakit campak pada tahun 2017 yaitu Kabupaten Kubu Raya sebanyak 109 kasus dari 32 kasus pada tahun 2016 [2].

Penelitian ini mengkaji dan mengembangkan model matematika pada penyebaran penyakit campak dengan pengaruh program kesadaran, menentukan titik kesetimbangan dan menganalisis kestabilan serta menginterpretasikannya dengan melakukan simulasi numerik. Pembentukan model matematika tersebut dikelompokkan menjadi empat subpopulasi yaitu subpopulasi yang rentan $(S)$, subpopulasi yang terinfeksi $(I)$, subpopulasi yang sembuh $(R)$ dan subpopulasi rentan yang sadar $\left(S_{m}\right)$ serta terdapat satu pengaruh yaitu pengaruh program kesadaran. Program kesadaran yang dimaksud dalam penelitian ini yaitu penyuluhan.

Pemodelan matematika dan analisis kestabilan model penyebaran penyakit campak dimulai dengan melihat masalah nyata untuk merancang asumsi dan mendefinisikan parameter yang digunakan pada model dan kemudian dibentuk ke dalam model matematika penyebaran penyakit campak. Selanjutnya, menentukan titik kesetimbangan dari model. Model yang diperoleh merupakan model dengan bentuk sistem persamaan diferensial nonlinear yang memiliki dua titik kesetimbangan yaitu titik kesetimbangan bebas penyakit dan titik kesetimbangan endemik penyakit. Setelah itu, dilakukan linearisasi model dengan membentuk matriks Jacobian dari sistem persamaan. Berdasarkan hasil dari matriks Jacobian, diperoleh persamaan karakteristik dan kemudian dicari determinan dari submatriks utama pembuka dari matriks Hurwitz untuk menentukan analisis kestabilannya. Langkah terakhir 
adalah melakukan simulasi numerik ke dalam determinan dari submatriks utama pembuka matriks Hurwitz pada masing-masing titik kesetimbangan yang kemudian dianalisis berdasarkan sifat stabilitas sistem dan menginterpretasikannya.

\section{MODEL MATEMATIKA PENYEBARAN PENYAKIT CAMPAK}

Model matematika penyebaran penyakit campak merupakan suatu model matematika yang menggambarkan dinamika penyebaran penyakit campak. Di dalam penelitian ini diasumsikan terdapat empat subpopulasi yaitu subpopulasi yang rentan $(S)$, subpopulasi yang terinfeksi $(I)$, subpopulasi yang sembuh $(R)$ dan subpopulasi rentan yang sadar $\left(S_{m}\right)$, serta terdapat satu pengaruh yaitu pengaruh program kesadaran $(M)$. Model matematika penyebaran penyakit campak dengan pengaruh program kesadaran sebagai berikut:

a. Subpopulasi rentan mengalami peningkatan karena adanya tingkat kelahiran alami $(\kappa)$. Selain itu, subpopulasi rentan juga mengalami penurunan karena adanya tingkat kematian alami $(\rho)$, tingkat penularan terinfeksi campak $(\beta)$ sehingga masuk ke subpopulasi terinfeksi dan mengalami pengurangan karena adanya tingkat penyebaran kesadaran $(\delta)$.

b. Subpopulasi terinfeksi mengalami peningkatan karena adanya tingkat penularan terinfeksi campak $(\beta)$. Subpopulasi terinfeksi juga mengalami penurunan karena adanya tingkat kematian alami $(\rho)$ dan kematian yang disebabkan oleh penyakit campak $(\eta)$. Selain itu, penurunan jumlah subpopulasi terinfeksi juga disebabkan karena adanya tingkat pemulihan alami $(\gamma)$ dan tingkat pemulihan karena pengaruh dari program kesadaran $\left(\gamma_{m}\right)$.

c. Subpopulasi yang sembuh mengalami peningkatan karena adanya tingkat pemulihan alami $(\gamma)$ dan tingkat pemulihan karena pengaruh dari program kesadaran $\left(\gamma_{m}\right)$. Berkurangnya jumlah subpopualsi yang sembuh diakibatkan karena adanya tingkat kematian alami $(\rho)$.

d. Subpopulasi rentan yang sadar mengalami peningkatan karena adanya pengaruh dari tingkat penyebaran kesadaran $(\delta)$ dan mengalami penurunan karena adanya tingkat kematian alami $(\rho)$.

Selain ke empat subpopulasi terdapat satu pengaruh yang dapat mempengaruhi penyebaran penyakit campak yaitu pengaruh dari program kesadaran. Terdapat tingkat pengaruh program kesadaran jumlah terinfeksi $(\mu)$ dan mengalami pengurangan tingkat pengaruh program kesadaran karena adanya ketidakberhasilan dari program kesadaran $\left(\mu_{0}\right)$ dengan representasi pada Gambar 1.

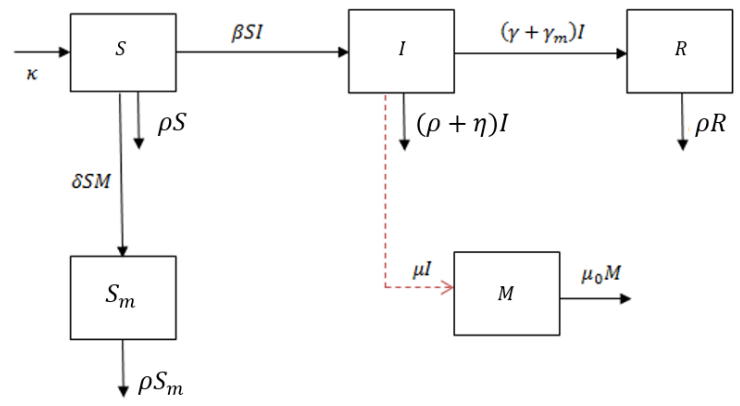

Gambar 1. Diagram Transfer Proses Penyebaran Penyakit Campak

Berdasarkan Gambar 1, diperoleh model matematika penyebaran penyakit campak sebagai berikut:

$$
\left\{\begin{array}{l}
\frac{d S}{d t}=\kappa-\beta S I-\delta S M-\rho S \\
\frac{d I}{d t}=\beta S I-(\rho+\eta) I-\left(\gamma+\gamma_{m}\right) I \\
\frac{d R}{d t}=\left(\gamma+\gamma_{m}\right) I-\rho R \\
\frac{d S_{m}}{d t}=\delta S M-\rho S_{m} \\
\frac{d M}{d t}=\mu I-\mu_{0} M
\end{array}\right.
$$


dengan $S, I, R, S_{m}, M \geq 0$ dan $\kappa, \beta, \delta, \rho, \eta, \gamma, \gamma_{\mathrm{m}}, \mu, \mu_{0}>0$.

Selanjutnya adalah menentukan titik kesetimbangan dari Sistem Persamaan (1). Berdasarkan Sistem (1) diperoleh dua titik kesetimbangan yaitu titik kesetimbangan bebas penyakit $\left(T K_{1}\right)$ dan titik kesetimbangan endemik penyakit $\left(T K_{2}\right)$ sebagai berikut:

$$
\begin{aligned}
T K_{1}=(S & \left.=\frac{\kappa}{\rho}, I=0, R=0, S_{m}=0, M=0\right), \\
T K_{2}=\left(S=\frac{\rho+\eta+\gamma+\gamma_{m}}{\beta},\right. & \\
I & =\frac{\left(\kappa \beta-\rho-\eta-\gamma-\gamma_{m}\right) \mu_{0}}{\beta \rho \mu_{0}+\beta \eta \mu_{0}+\beta \gamma \mu_{0}+\beta \gamma_{M} \mu_{0}+\delta \rho \mu+\delta \eta \mu+\delta \gamma \mu+\delta \gamma_{m} \mu}, \\
R & =\frac{\left(\gamma+\gamma_{m}\right)\left(\kappa \beta-\rho-\eta-\gamma-\gamma_{m}\right)}{\left(\beta \rho \mu_{0}+\beta \eta \mu_{0}+\beta \gamma \mu_{0}+\beta \gamma_{m} \mu_{0}+\delta \rho \mu+\delta \eta \mu+\delta \gamma \mu+\delta \gamma_{m} \mu\right) \rho}, \\
S_{m} & =\frac{\delta \mu\left(\kappa \beta-\rho-\eta-\gamma-\gamma_{m}\right)}{\beta \rho\left(\beta \mu_{0}+\delta \mu\right)}, \\
M & \left.=\frac{\mu\left(\kappa \beta-\rho-\eta-\gamma-\gamma_{m}\right)}{\beta \rho \mu_{0}+\beta \eta \mu_{0}+\beta \gamma \mu_{0}+\beta \gamma_{M} \mu_{0}+\delta \rho \mu+\delta \eta \mu+\delta \gamma \mu+\delta \gamma_{m} \mu}\right) .
\end{aligned}
$$

Titik kesetimbangan $T K_{1}$ menunjukkan kondisi bebas penyakit pada suatu daerah dengan adanya pengaruh program kesadaran. Kondisi ini menunjukkan tidak adanya individu yang terinfeksi campak. Titik kesetimbangan $T K_{2}$ menunjukkan kondisi masih adanya penyakit campak dalam suatu subpopulasi pada suatu daerah karena ketidakberhasilan dari program yang dijalankan sehingga masih ada subpopulasi yang terinfeksi campak.

\section{ANALISIS KESTABILAN MODEL PENYEBARAN PENYAKIT CAMPAK}

Analisis kestabilan sistem persamaan diferensial nonlinear pada penelitian ini dilakukan dengan menggunakan kriteria Routh-Hurwitz yaitu dengan memperhatikan nilai detereminan dari submatriks utama pembuka dari matriks Hurwitz $\mathbf{H}$, dengan $\mathbf{H} \in \mathbb{R}^{\boldsymbol{n} \times \boldsymbol{n}}$ yang dapat ditulis sebagai berikut:

$$
\mathbf{H}=\left[\begin{array}{cccccc}
\mathrm{a}_{1} & \mathrm{a}_{3} & \mathrm{a}_{5} & \mathrm{a}_{7} & \cdots & 0 \\
1 & \mathrm{a}_{2} & \mathrm{a}_{4} & \mathrm{a}_{6} & \cdots & 0 \\
0 & \mathrm{a}_{1} & \mathrm{a}_{3} & \mathrm{a}_{5} & \cdots & 0 \\
0 & 1 & \mathrm{a}_{2} & \mathrm{a}_{4} & \cdots & 0 \\
\vdots & \vdots & \vdots & \vdots & \ddots & \vdots \\
0 & 0 & 0 & 0 & \cdots & \mathrm{a}_{\mathrm{n}}
\end{array}\right] .
$$

Syarat cukup dan perlu untuk kestabilan sistem di sekitar titik kesetimbangan jika semua determinan dari submatriks utama pembuka dari matriks $\mathbf{H}$ adalah positif. Kriteria kestabilan juga ditentukan oleh $\operatorname{det} \mathbf{H} \neq 0$ [3].

Analisis kestabilan sistem persamaan diferensial nonlinear dilakukan dengan linearisasi terlebih dahulu. Linearisasi dilakukan dengan menggunakan matriks Jacobian dari Sistem Persamaan (1) sehingga diperoleh matriks J sebagai berikut:

$$
\mathbf{J}=\left(\begin{array}{ccccc}
-\beta I-\delta M-\rho & -\beta S & 0 & 0 & -\delta S \\
\beta I & \beta S-\rho-\eta-\gamma-\gamma_{M} & 0 & 0 & 0 \\
0 & \gamma+\gamma_{m} & -\rho & 0 & 0 \\
\delta M & 0 & 0 & -\rho & \delta S \\
0 & \mu & 0 & 0 & -\mu_{0}
\end{array}\right) .
$$

Selanjutnya, substitusikan Persamaan (2) ke Persamaan (4). Nilai eigen dari model matematika penyebaran penyakit campak diperoleh jika dan hanya jika $\operatorname{det}(\mathbf{J}-\lambda \mathbf{I})=0$, dengan $\mathbf{J}$ merupakan matriks Jacobian sebagai matriks linearisasi dari Sistem (1), $\lambda$ merupakan nilai eigen dan I merupakan matriks identitas. Persamaan karakteristik untuk titik kesetimbangan bebas penyakit yaitu $\operatorname{det}\left(\mathbf{J}_{\mathbf{1}}-\right.$ $\lambda \mathbf{I})=0$, sehingga diperoleh: 


$$
\operatorname{det}\left(\begin{array}{ccccc}
\lambda+\rho & \beta\left(\frac{\kappa}{\rho}\right) & 0 & 0 & \delta\left(\frac{\kappa}{\rho}\right) \\
0 & \lambda-\beta\left(\frac{\kappa}{\rho}\right)+\rho+\eta+\gamma+\gamma_{m} & 0 & 0 & 0 \\
0 & -\gamma-\gamma_{m} & \lambda+\rho & 0 & 0 \\
0 & 0 & 0 & \lambda+\rho & -\delta\left(\frac{\kappa}{\rho}\right) \\
0 & 0 & 0 & 0 & \lambda+\mu_{0}
\end{array}\right)=0
$$

dengan $\mathbf{J}_{\mathbf{1}}$ merupakan matriks Jacobian sebagai matriks linearisasi dari Sistem (1) untuk titik kesetimbangan bebas penyakit campak. Berdasarkan Persamaan (5) diperoleh polinomial karakteristik sebagai berikut:

$$
\lambda^{5}+A_{1} \lambda^{4}+B_{1} \lambda^{3}+C_{1} \lambda^{2}+D_{1} \lambda+E_{1}
$$

dengan nilai $A_{1}, B_{1}, C_{1}, D_{1}$ dan $E_{1}$ sebagai berikut:

$$
\begin{aligned}
A_{1}= & \mu_{0}+4 \rho-\frac{\beta \kappa}{\rho}+\eta+\gamma+\gamma_{m} \\
B_{1}= & 2 \rho \mu_{0}+2 \mu_{0}+8 \rho^{2}+\mu_{0} \eta+3 \rho \eta+\mu_{0} \gamma+2 \rho \gamma+\mu_{0} \gamma_{m}+3 \rho \gamma_{m}-\frac{\beta \kappa \mu_{0}}{\rho}-\beta \kappa \\
C_{1}= & 4 \rho^{2} \mu_{0}+4 \rho^{3}-\beta \kappa \mu_{0}-\beta \kappa-\frac{\beta \kappa \mu_{0}}{\rho}-3 \beta \kappa \rho+2 \mu_{0} \rho+\rho \mu_{0} \eta+2 \mu_{0} \eta+2 \rho^{2} \eta+\rho \eta+\rho \mu_{0} \gamma+2 \\
& \mu_{0} \gamma+3 \rho^{2} \gamma+\rho \mu_{0} \gamma_{m}+2 \mu_{0} \gamma_{m}+3 \rho^{2} \gamma_{m} \\
D_{1}= & 2 \rho^{3} \mu_{0}-3 \beta \kappa \rho \mu_{0}-\beta \kappa \rho^{2}+2 \rho^{3} \mu_{0}+\rho^{4}+3 \rho^{2} \mu_{0} \eta+\rho^{3} \eta+3 \rho^{2} \mu_{0} \gamma+\rho^{3} \gamma+3 \rho^{2} \mu_{0} \gamma_{m}+\rho^{3} \\
& \gamma_{m} \\
E_{1}= & \beta \kappa \rho^{2} \mu_{0}+\rho^{3} \mu_{0} \eta+\rho^{3} \mu_{0} \gamma+\rho^{3} \mu_{0} \gamma_{m}
\end{aligned}
$$

Berdasarkan nilai koefisien polinomial pada Persamaan (6) diperoleh matriks Hurwitz sebagai berikut:

$$
\mathbf{H}_{\mathbf{1}}=\left(\begin{array}{ccccc}
A_{1} & C_{1} & E_{1} & 0 & 0 \\
1 & B_{1} & D_{1} & 0 & 0 \\
0 & A_{1} & C_{1} & E_{1} & 0 \\
0 & 1 & B_{1} & D_{1} & 0 \\
0 & 0 & A_{1} & C_{1} & E_{1}
\end{array}\right),
$$

dengan determinan dari submatriks utama pembuka matriks Hurwitz Persamaan (7), yaitu:

$H_{1}=A_{1}$

$H_{2}=\left|\begin{array}{cc}A_{1} & C_{1} \\ 1 & B_{1}\end{array}\right|=A_{1} B_{1}-C_{1}$,

$H_{3}=\left|\begin{array}{ccc}A_{1} & C_{1} & E_{1} \\ 1 & B_{1} & D_{1} \\ 0 & A_{1} & C_{1}\end{array}\right|=A_{1} B_{1} C_{1}+E_{1} A_{1}-A_{1}{ }^{2} D_{1}-C_{1}{ }^{2}$

$H_{4}=\left|\begin{array}{cccc}A_{1} & C_{1} & E_{1} & 0 \\ 1 & B_{1} & D_{1} & 0 \\ 0 & A_{1} & C_{1} & E_{1} \\ 0 & 1 & B_{1} & D_{1}\end{array}\right|=A_{1} B_{1} C_{1} D_{1}+A_{1} B_{1}{ }^{2} E_{1}-A_{1}{ }^{2} D_{1}{ }^{2}+2 A_{1} D_{1} E_{1}-C_{1}{ }^{2} D_{1}+C_{1} B_{1} E_{1}-E_{1}{ }^{2}$,

$H_{5}=\left|\begin{array}{ccccc}A_{1} & C_{1} & E_{1} & 0 & 0 \\ 1 & B_{1} & D_{1} & 0 & 0 \\ 0 & A_{1} & C_{1} & E_{1} & 0 \\ 0 & 1 & B_{1} & D_{1} & 0 \\ 0 & 0 & A_{1} & C_{1} & E_{1}\end{array}\right|$

$$
=A_{1} B_{1} C_{1} D_{1} E_{1}-A_{1} B_{1}{ }^{2} E_{1}{ }^{2}-A_{1}{ }^{2} E_{1}{ }^{2} E_{1}+2 A_{1} D_{1} E_{1}{ }^{2}-C_{1}{ }^{2} D_{1} E_{1}+C_{1} B_{1} E_{1}{ }^{2}-E_{1}{ }^{3} .
$$

Berdasarkan nilai $H_{1}, H_{2}, H_{3}, H_{4}$ dan $H_{5}$ sistem akan stabil asimtotik jika:

1. $H_{1}>0$, berarti $A_{1}>0$,

2. $H_{2}>0$, berarti $A_{1} B_{1}>C_{1}$,

3. $H_{3}>0$, berarti $A_{1} B_{1} C_{1}+E_{1} A_{1}>A_{1}^{2} D_{1}+C_{1}^{2}$,

4. $H_{4}>0$, berarti $A_{1} B_{1} C_{1} D_{1}+A_{1} B_{1}{ }^{2} E_{1}+2 A_{1} D_{1} E_{1}+C_{1} B_{1} E_{1}>A_{1}{ }^{2} D_{1}{ }^{2}+C_{1}{ }^{2} D_{1}+E_{1}{ }^{2}$, 
5. $H_{5}>0$, berarti $A_{1} B_{1} C_{1} D_{1} E_{1}+2 A_{1} D_{1} E_{1}{ }^{2}+C_{1} B_{1} E_{1}{ }^{2}>A_{1} B_{1}{ }^{2} E_{1}{ }^{2}+A_{1}{ }^{2} E_{1}{ }^{2} E_{1}+C_{1}{ }^{2} D_{1} E_{1}+E_{1}{ }^{3}$.

Selanjutnya menentukan kestabilan dari Sistem (1) untuk titik kesetimbangan endemik penyakit. Persamaan karakteristik untuk titik kesetimbangan bebas penyakit yaitu $\operatorname{det}\left(\mathbf{J}_{2}-\lambda \mathbf{I}\right)=0$, sehingga diperoleh:

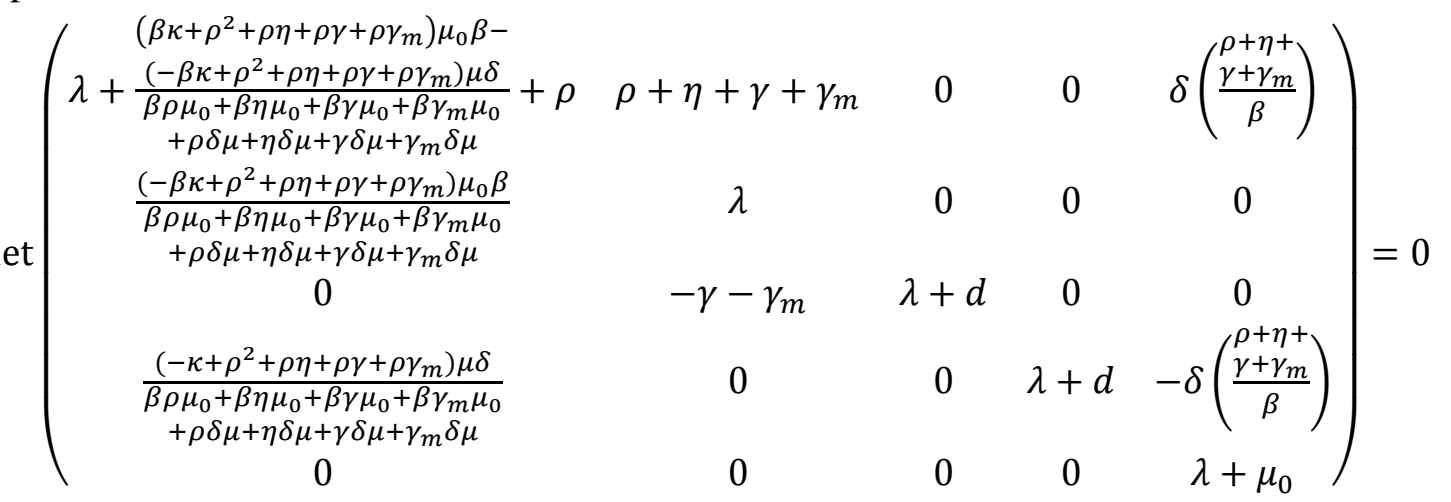

dengan $\mathbf{J}_{2}$ merupakan matriks Jacobian sebagai matriks linearisasi dari Sistem (1) untuk titik kesetimbangan bebas penyakit campak. Berdasarkan Persamaan (8) diperoleh polinomial karakteristik sebagai berikut:

$$
\lambda^{5}+A_{2} \lambda^{4}-B_{2} \lambda^{3}-C_{2} \lambda^{2}-D_{2} \lambda-E_{2}
$$

dengan nilai $A_{2}, B_{2}, C_{2}, D_{2}$ dan $E_{2}$ sebagai berikut:

$$
\begin{aligned}
A_{2}= & \frac{\beta \kappa+2 \rho^{2}+2 \rho \eta+2 \rho \gamma+2 \rho \gamma_{m}+\rho \mu_{0}+\eta \mu_{0}+\gamma \mu_{0}+\gamma_{m} \mu_{0}}{\rho+\eta+\gamma+\gamma_{m}} \\
B_{2}= & -\frac{1}{\left(\rho+\eta+\gamma+\gamma_{m}\right)\left(\beta \mu_{0}+\delta \mu\right)}\left(-3 \beta^{2} \rho \kappa \mu_{0}-\beta^{2} \eta \kappa \mu_{0}-\beta^{2} \gamma \kappa \mu_{0}-\beta^{2} \gamma_{m} \kappa \mu_{0}-\beta^{2} \kappa \mu_{0}^{2}+\beta \rho^{2}\right. \\
& \eta \mu_{0}+\beta \rho^{2} \gamma \mu_{0}+\beta \rho^{2} \gamma_{m} \mu_{0}-2 \beta \rho^{2} \mu_{0}^{2}-2 \beta \rho \delta \kappa \mu+\beta \rho \eta^{2} \mu_{0}+2 \beta \rho \eta \gamma \mu_{0}+2 \beta \rho \eta \gamma_{m} \mu_{0}-2 \beta \rho \eta \\
& \mu_{0}^{2}+\beta \rho \gamma^{2} \mu_{0}+2 \beta \rho \gamma \gamma_{m} \mu_{0}+\gamma_{m}^{2} \mu_{0}-2 \beta \rho \gamma_{m} \mu_{0}^{2}-\beta \delta \kappa \mu \mu_{0}-\rho^{3} \delta \mu-\rho^{2} \delta \eta \mu-\rho^{2} \delta \gamma \mu-\rho^{2} \delta \gamma_{m} \\
& \left.\mu-2 \rho^{2} \delta \mu \mu_{0}-2 \rho \eta \delta \mu \mu_{0}-2 \rho \gamma \delta \mu \mu_{0}-2 \rho \gamma_{m} \delta \mu \mu_{0}\right) \\
C_{2}= & -\frac{1}{\left(\rho+\eta+\gamma+\gamma_{m}\right)\left(\beta \mu_{0}+\delta \mu\right)}\left(-3 \beta^{2} \rho^{2} \kappa \mu_{0}-2 \beta^{2} \rho \eta \kappa \mu_{0}-2 \beta^{2} \rho \gamma \kappa \mu_{0}-2 \beta^{2} \rho \gamma_{m} \kappa \mu_{0}-3 \beta^{2}\right. \\
& \rho \eta \kappa \mu_{0}^{2}-\beta^{2} \gamma \kappa \mu_{0}^{2}-\beta^{2} \kappa \gamma_{m} \mu_{0}^{2}+2 \beta \rho^{4} \mu_{0}+4 \beta \rho^{3} \eta \mu_{0}+4 \beta \rho^{3} \gamma \mu_{0}+4 \beta \rho^{3} \gamma_{m} \mu_{0}-2 \beta \rho^{2} \delta \kappa \mu+2 \\
& \beta \rho^{2} \eta^{2} \mu_{0} \rho^{2}+4 \beta \eta \gamma \mu_{0}+4 \beta \rho^{2} \eta \gamma_{m} \mu_{0}+\beta \rho^{2} \eta \mu_{0}^{2}+2 \beta \rho^{2} \gamma^{2} \mu_{0}+4 \beta \rho^{2} \gamma \gamma_{m} \mu_{0}+\beta \rho^{2} \gamma \mu_{0}^{2}+2 \beta \\
& \rho^{2} \gamma_{m}^{2} \mu_{0}+\beta \rho^{2} \gamma_{m} \mu_{0}^{2}-3 \beta \rho \delta \kappa \mu \mu_{0}+\beta \rho \eta^{2} \mu_{0}^{2}+2 \beta \rho \eta \gamma \mu_{0}^{2}+2 \beta \rho \eta \gamma_{m} \mu_{0}^{2}+\beta \rho \gamma^{2} \mu_{0}^{2}+2 \beta \rho \gamma \gamma_{m} \mu_{0}^{2} \\
& +\beta \rho \gamma_{m}^{2} \mu_{0}^{2}-\beta \delta \eta \kappa \mu \mu_{0}-\beta \delta \gamma \kappa \mu \mu_{0}-\beta \delta \gamma_{m} \kappa \mu \mu_{0}+\rho^{2} \delta \eta \mu \mu_{0}+\rho^{2} \delta \gamma \mu \mu_{0}+\rho^{2} \delta \gamma_{m} \mu \mu_{0}+\rho \delta \eta^{2} \mu \\
& \left.\mu_{0}+2 \rho \delta \eta \mu \mu_{0}+2 \rho \delta \eta \gamma_{m} \mu \mu_{0}+\rho \delta \gamma^{2} \mu \mu_{0}+2 \rho \delta \gamma \gamma_{m} \mu \mu_{0}+\rho \delta \mu \gamma_{m}^{2} \mu_{0}\right) \\
D_{2}= & -\frac{1}{\left(\rho+\eta+\gamma+\gamma_{m}\right)\left(\beta \mu_{0}+\delta \mu\right)}\left(-\beta^{2} \rho^{2} \kappa-\beta^{2} \rho \eta \kappa-\beta^{2} \rho \gamma \kappa-\beta^{2} \rho \gamma_{m} \kappa-\beta^{2} \rho \kappa \gamma_{m}-3 \beta^{2} \rho \kappa\right.
\end{aligned}
$$$$
\mu_{0}-2 \beta^{2} \eta \kappa \mu_{0}-2 \beta^{2} \gamma \kappa \mu_{0}+2 \beta^{2} \gamma_{m} \kappa \mu_{0}+\beta \rho^{4}+2 \beta \rho^{3} \eta+2 \beta \rho^{3} \gamma+2 \beta \rho^{3} \gamma_{m}+2 \beta \rho^{3} \mu_{0}+\beta \rho^{2}
$$$$
\left.\eta^{2}+2 \beta \rho^{2} \eta \gamma+\beta \rho^{2} \eta \gamma_{m}+4 \beta \rho^{2} \eta \mu_{0}+\beta \rho^{2} \gamma^{2}+2 \beta \rho^{2} \gamma \gamma\right) m+4 \beta \rho^{2} \gamma \mu_{0}+\beta \rho^{2} \gamma_{m}^{2}+4 \beta \rho^{2} \gamma_{m}
$$$$
\mu_{0}-3 \beta \rho \delta \kappa \mu+2 \beta \rho \eta^{2} \mu_{0}+4 \beta \rho \eta \gamma \mu_{0}+4 \beta \rho \eta \gamma_{m} \mu_{0}+2 \beta \rho \gamma^{2} \mu_{0}+4 \beta \rho \gamma \gamma_{m} \mu_{0}+2 \beta \rho \gamma_{m}^{2} \mu_{0}-2
$$$$
\beta \delta \eta \kappa \mu-2 \beta \delta \gamma \kappa \mu-2 \beta \delta \gamma_{m} \kappa \mu+2 \rho^{3} \delta \mu+4 \rho^{2} \delta \eta \mu+4 \rho^{2} \delta \gamma \mu+4 \rho^{2} \delta \gamma_{m} \mu+2 \rho \delta \eta^{2} \mu+4 \rho \delta \eta \gamma
$$$$
\left.\mu+4 \rho \delta \eta \gamma_{m} \mu+2 \rho \delta \gamma^{2} \mu+4 \rho \delta \gamma \mu \gamma_{m}+2 \rho \delta \mu \gamma_{m}^{2}\right)
$$$$
E_{2}=-\mu_{0} \rho^{2}\left(-\beta \kappa+\rho^{2}+\rho \eta+\rho \gamma+\rho \gamma_{m}\right)
$$

Berdasarkan nilai koefisien polinomial pada Persamaan (9) diperoleh matriks Hurwitz sebagai berikut:

$$
\mathbf{H}_{2}=\left(\begin{array}{ccccc}
A_{2} & C_{2} & E_{2} & 0 & 0 \\
1 & B_{2} & D_{2} & 0 & 0 \\
0 & A_{2} & C_{2} & E_{2} & 0 \\
0 & 1 & B_{2} & D_{2} & 0 \\
0 & 0 & A_{2} & C_{2} & E_{2}
\end{array}\right),
$$

dengan determinannya dari submatriks utama pembuka matriks Hurwitz Persamaan (10), yaitu: 


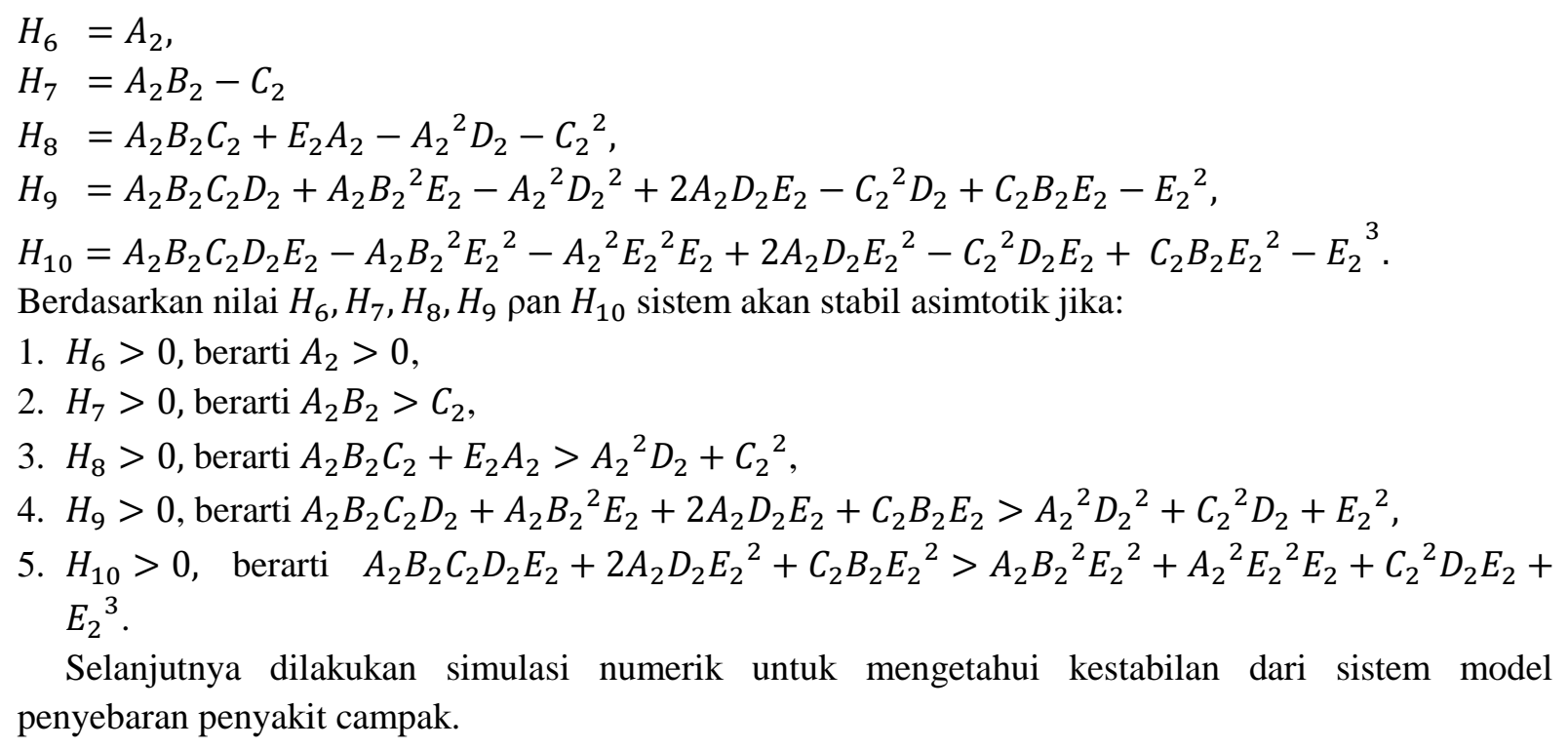

\section{SIMULASI DAN INTERPRETASI MODEL PENYEBARAN PENYAKIT CAMPAK}

Simulasi model dalam penelitian ini bertujuan untuk melihat dinamika penyebaran penyakit campak dengan pengaruh program kesadaran. Simulasi ini dilakukan dengan mensubstitusikan nilai parameter berikut:

Tabel 1. Nilai Parameter Penyebaran Penyakit Campak

\begin{tabular}{clc}
\hline Parameter & \multicolumn{1}{c}{ Nilai } & Sumber \\
\hline$\kappa$ & 0,0012167 & {$[4]$} \\
$\beta$ & 0,0000145 & {$[2]$} \\
$\delta$ & 0,0002 & {$[5]$} \\
$\rho$ & 0,00119388 & {$[4]$} \\
$\eta$ & 0,0000167 & {$[6]$} \\
$\gamma$ & 0,04 & {$[7]$} \\
$\gamma_{m}$ & 0,01 & {$[5]$} \\
$\mu$ & 0,13 & {$[8]$} \\
$\mu_{0}$ & 0,625 & {$[8]$}
\end{tabular}

Nilai-nilai parameter pada Tabel 1 disubstitusikan ke Sistem (1), dengan niai awal $S=9.243$ (Jumlah individu yang lahir masuk ke subpopulasi rentan perbulan), $I=10$ (jumlah yang terinfeksi campak perbulan), $R=28.500$ (Jumlah individu yang sembuh dan tidak terserang campak perbulan), $S_{m}=$ 9.089 (jumlah remaja berusia 10 sampai 19 tahun perbulan) dan $M=21$ (banyaknya penyuluhan perbulan). Berdasarkan langkah-langkah yang telah dijelaskan pada analisis kestabilan penyebaran penyakit campak, diperoleh determinan dari submatriks utama pembuka matriks Hurwitz Sistem (1) yang telah dilakukan simulasi data sebagai berikut:

Tabel 2. Nilai Determinan dari submatriks utama pembuka matriks Hurwitz Model Penyebaran Penyakit Campak

\begin{tabular}{|c|c|}
\hline $\begin{array}{l}\text { Nilai determinan dari submatriks } \\
\text { utama pembuka matriks Hurwitz } \\
\text { Titik Kesetimbangan Bebas Penyakit }\end{array}$ & $\begin{array}{l}\text { Nilai determinan dari submatriks } \\
\text { utama pembuka matriks Hurwitz } \\
\text { Titik Kesetimbangan Endemik Penyakit }\end{array}$ \\
\hline$H_{1}=0,06942777214$ & $H_{6}=0,02688820114$ \\
\hline$=0,001454616938$ & $H_{7}=0,000002750105653$ \\
\hline$=0,000002949935429$ & $H_{8}=-1,196544524 \times 10^{-12}$ \\
\hline$=1,298625882 \times 10^{-14}$ & $H_{9}=3,549024792 \times 10^{-21}$ \\
\hline$=2,175551035 \times 10^{-26}$ & $H_{10}=-6,664183118 \times 10^{-33}$ \\
\hline
\end{tabular}


Berdasarkan Tabel 2 dengan titik kesetimbangan bebas penyakit campak diperoleh kestabilan sistem yaitu stabil asimtotik.

Selanjutnya hasil simulasi numerik model penyebaran penyakit campak untuk $t=0$ sampai $t=120$ bulan mendatang dapat dilihat pada Gambar 2.

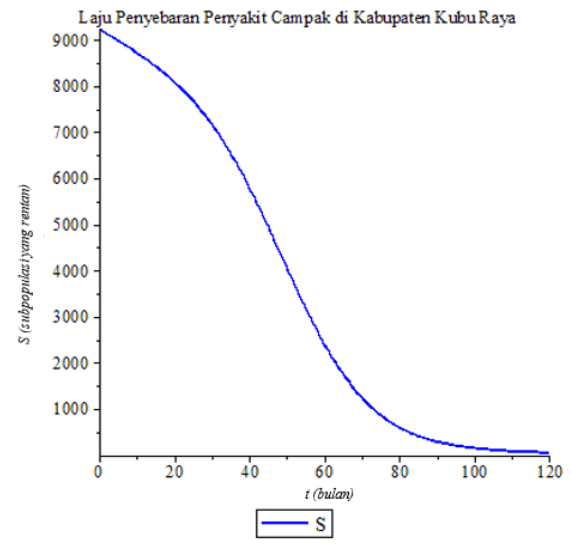

(a)

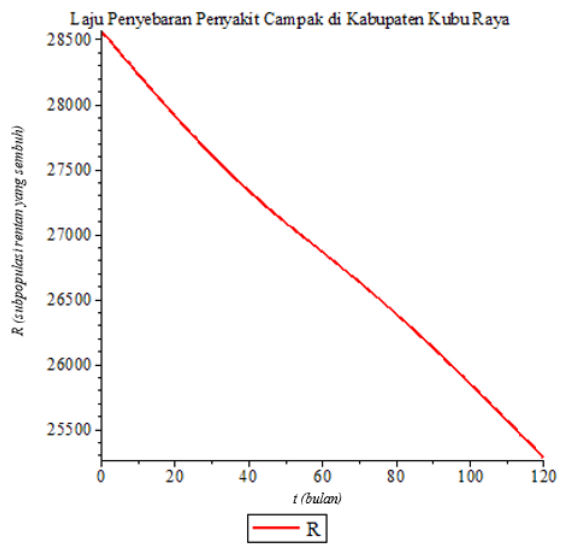

(c)

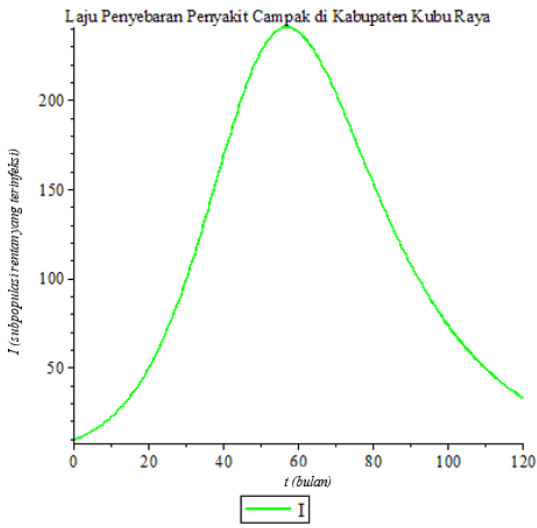

(b)

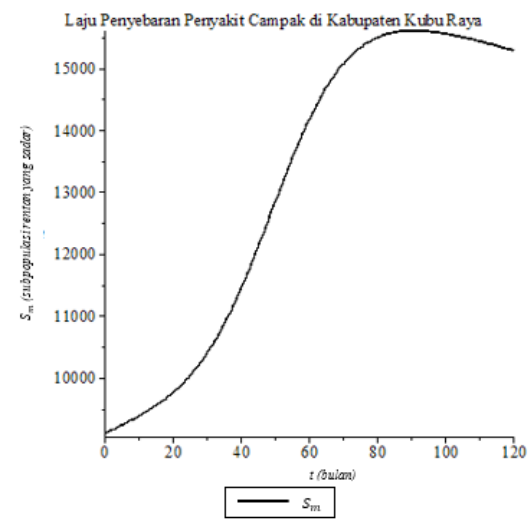

(d)

Gambar 2. Grafik Simulasi Penyebaran Penyakit Campak (a) Subpopulasi Rentan (b) Subpopulasi Terinfeksi (c) Subpopulasi yang Sembuh (d) Subpopulasi rentan yang Sadar

Berdasarkan Gambar 2 (a) terlihat bahwa jumlah individu pada subpopulasi $S$ mengalami penurunan, dari mula-mula manusia yang rentan berjumlah 9.243 orang pada waktu $t=0$ bulan menjadi kurang lebih 50 orang yang rentan pada waktu $t=120$ bulan. Hal ini disebabkan karena meningkatnya jumlah interaksi antara individu yang rentan dan terinfeksi sehingga individu pada subpopulasi terinfeksi meningkat. Selain itu, hal tersebut juga disebabkan karena adanya kematian alami dan pemberian informasi akan penyakit campak yang menyadarkan manusia akan penyakit campak sehingga subpopulasi $S$ menurun.

Berdasarkan Gambar 2 (b) terlihat bahwa jumlah individu pada subopulasi $I$ mengalami peningkatan, dari mula-mula manusia yang terinfeksi berjumlah 10 orang pada waktu $t=0$ bulan menjadi sekitar 240 orang yang terinfeksi kurang lebih pada waktu $t=55$ bulan. Hal ini disebabkan karena meningkatnya jumlah interaksi antara individu yang terinfeksi dengan individu yang rentan sehingga menyebabkan jumlah subpopulasi terinfeksi bertambah. Namun, kurang lebih pada $t=58$ bulan dan seterusnya jumlah individu pada subpopulasi terinfeksi mengalami penurunan sehingga pada waktu $t=120$ bulan menjadi sekitar 33 orang karena adanya kematian alami serta kematian yang disebabkan karena penyakit. Selain itu, penurunan juga disebabkan karena ada dari anggota subpopulasi terinfeksi sembuh dari penyakit campak. 
Berdasarkan Gambar 2 (c) terlihat bahwa jumlah individu pada subpopulasi $R$ mengalami penurunan, dari mula-mula manusia yang kebal terhadap penyakit berjumlah 28.500 orang pada waktu $t=0$ mengalami penurunan menjadi kurang lebih 25.300 orang yang sembuh pada waktu $t=120$ bulan. Hal ini disebabkan karena adanya kematian alami.

Berdasarkan Gambar 2 (d) terlihat bahwa jumlah individu pada subpopulasi $S_{m}$ mengalami peningkatan dari mula-mula manusia rentan yang sadar berjumlah 9.089 orang pada waktu $t=0$ bulan menjadi sekitar 15.500 orang retan yang sadar kurang lebih pada waktu $t=85$ bulan. Hal ini disebabkan karena meningkatnya program yang dijalankan untuk kesadaran manusia tentang penyakit campak. Namun, kurang lebih pada waktu $t=98$ bulan dan seterusnya jumlah individu pada subpopulasi rentan yang sadar mengalami penurunan menjadi kurang lebih 15.300 Orang pada waktu $t=120$ bulan yang disebabkan karena adanya kematian alami.

Selanjutnya grafik pengaruh dari program kesadaran terhadap penyebaran penyakit campak yang dilihat pada Gambar 3 sebagai berikut:

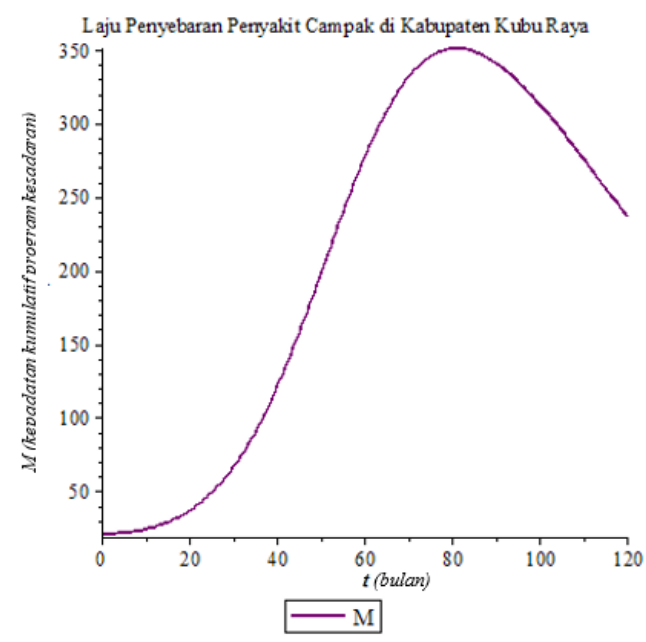

(a)

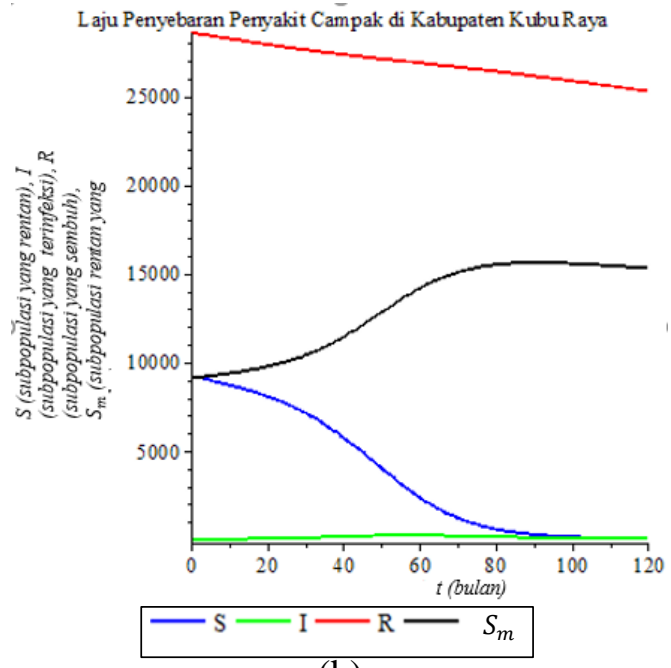

(b)

Gambar 3. Grafik Tingkat Pengaruh Program Kesadaran pada Penyakit Campak (a) Pengaruh Program Kesadaran (b) Penyebaran Penyakit Campak dengan Subpopulasi Rentan, Subpopulasi Terinfeksi, Subpopulasi yang Sembuh dan Subpopulasi Rentan yang Sadar

Berdasarkan Gambar 3 dapat dilihat pengaruh dari program kesadaran di kabupaten Kubu Raya meningkat dikarenakan meningkatnya jumlah populasi terinfeksi di kabupaten tersebut. Program yang dijalankan pada waktu $t=0$ sebanyak 21 mengalami peningkatan menjadi 350 program pada waktu $t=77$ bulan karena meningkatnya jumlah populasi penyakit campak akibat penyebaran penyakitnya. Jadi, semakin besar penyebaran penyakit campak maka semakin besar pula program yang akan dijalankan agar subpopulasi rentan mendapatkan informasi tentang penyakit campak sehingga supopulasi rentan yang sadar juga meningkat. Hal tersebut dapat mengurangi jumlah subpopulasi rentan terhadap penyakit campak karena adanya pemisahan antara subpopulasi rentan pindah ke subpopulasi rentan yang sadar karena adanya pengaruh dari program kesadaran. Sehingga, program kesadaran merupakan salah satu cara yang dapat dilakukan untuk mengurangi penyebaran penyakit campak.

\section{PENUTUP}

Model matematika penyebaran penyakit campak yaitu:

$$
\begin{array}{ll}
\frac{d S}{d t}=\kappa-\beta S I-\delta S M-d S, & \frac{d S_{m}}{d t}=\delta S M-d S_{m} \\
\frac{d I}{d t}=\beta S I-(d+\eta) I-\left(\gamma+\gamma_{m}\right) I, & \frac{d M}{d t}=\mu I-\mu_{0} M
\end{array}
$$


$\frac{d R}{d t}=\left(\gamma+\gamma_{m}\right) I-d R$

Model matematika tersebut menghasilkan dua titik kesetimbangan, yaitu:

a. Titik kesetimbangan bebas penyakit

$$
T K_{1}=\left(S_{1}=\frac{\kappa}{\rho}, I_{1}=0, R_{1}=0, S_{m 1}=0, M_{1}=0\right)
$$

b. Titik kesetimbangan endemi penyakit

$$
\begin{aligned}
T K_{2}=\left(S_{2}\right. & =\frac{\rho+\eta+\gamma+\gamma_{m}}{\beta}, \\
I_{2} & =\frac{\left(\kappa \beta-\rho-\eta-\gamma-\gamma_{m}\right) \mu_{0}}{\beta \rho \mu_{0}+\beta \eta \mu_{0}+\beta \gamma \mu_{0}+\beta \gamma_{M} \mu_{0}+\delta \rho \mu+\delta \eta \mu+\delta \gamma \mu+\delta \gamma_{m} \mu} \\
R_{2} & =\frac{\left(\gamma+\gamma_{m}\right)\left(\kappa \beta-\rho-\eta-\gamma-\gamma_{m}\right)}{\left(\beta \rho \mu_{0}+\beta \eta \mu_{0}+\beta \gamma \mu_{0}+\beta \gamma_{m} \mu_{0}+\delta \rho \mu+\delta \eta \mu+\delta \gamma \mu+\delta \gamma_{m} \mu\right) \rho}, \\
S_{m 2} & =\frac{\delta \mu\left(\kappa \beta-\rho-\eta-\gamma-\gamma_{m}\right)}{\beta \rho\left(\beta \mu_{0}+\delta \mu\right)}, \\
M_{2} & \left.=\frac{\mu\left(\kappa \beta-\rho-\eta-\gamma-\gamma_{m}\right)}{\beta \rho \mu_{0}+\beta \eta \mu_{0}+\beta \gamma \mu_{0}+\beta \gamma_{M} \mu_{0}+\delta \rho \mu+\delta \eta \mu+\delta \gamma \mu+\delta \gamma_{m} \mu}\right),
\end{aligned}
$$

dengan nilai determinan dari submatriks utama pembuka dari matriks Hurwitz yaitu:

a. Determinan dari submatriks utama pembuka matriks Hurwitz untuk titik kesetimbangan bebas penyakit yaitu $H_{1}=0,06942777214, H_{2}=0,001454616938, H_{3}=0,000002949935429$, $H_{4}=1,298625882 \times 10^{-14}$ dan $H_{5}=2,175551035 \times 10^{-26}$,

Sehingga diperoleh bahwa sistem untuk titik kesetimbangan bebas penyakit adalah stabil asimtotik.

b. Determinan dari submatriks utama pembuka matriks Hurwitz untuk titik kesetimbangan endemik penyakit yaitu $H_{6}=0,02688820114, H_{7}=0,000002750105653, H_{8}=-1,196544524 \times$ $10^{-12}, H_{9}=3,549024792 \times 10^{-21}$ dan $H_{10}=-6,664183118 \times 10^{-33}$

Sehingga diperoleh bahwa sistem untuk titik kesetimbangan endemik penyakit adalah tidak stabil.

Berdasarkan interpretasi yang didapat dari simulasi numerik menunjukkan bahwa program kesadaran membantu untuk mengurangi penyebaran penyakit campak dengan melakukan pemisahan sebagian kerentanan subpopulasi yaitu adanya perpindahan subpopulasi rentan menuju subpopulasi rentan yang sadar karena adanya pengaruh program kesadaran dengan mendapatkan informasi melalui penyuluhan sehingga mengurangi penyebaran infeksi campak.

\section{DAFTAR PUSTAKA}

[1]. Widoyono. Penyakit Tropis: Epidemilogi, Penularan, Pencegahan dan Pemberantasannya. Jakarta: Erlangga; 2011.

[2]. Dinas Kesehatan Provinsi Kalimantan Barat. Profil Kesehatan Provinsi Kalimantan Barat Tahun 2017. Pontianak: Dinas Kesehatan;2017.

[3]. Kraus FJ, Mansour M, Sebek M. Hurwitz Matrix for Polynomial Matrices. International Series of Numerical Mathematics. Switzerland. 1996; 121.

[4]. Badan Pusat Statistik Kabupaten Kubu Raya. Kabupaten Kubu Raya dalam Angka 2018. Kubu Raya: Badan Pusat Statistik; 2018.

[5]. Kaur N, Ghosh M,Bhatia SS. Modeling and Analysisnof an SIRS Epidemic Model with Effect of Awareness Programs by Media. Word Academy of Science, Enggineering and Technology International Journal of Mathematical and Computational Sciences. 2014; 8.

[6]. Juniarti, Kunoli FJ, Afni N. Faktor Risiko Campak di Dusun Wandu Desa Salulomba Wilayah Kerja Puskesamas Donggala. Promotif. 2016; 6: 45-54 
[7]. Aziziah AN, Abadi. Model SIR Epidemi Penyakit Campak Berdasarkan Umur dengan Pengaruh Imunisasi. Jurnal Ilmiaj Matematika. 2017; 3.

[8]. Dinas Kesehatan Kabupaten Kubu Raya. Profil Kesehatan Kabupaten Kubu Raya. Sungai Raya: Dinas Kesehatan; 2017.

$\begin{array}{cc}\text { RIMALIA } & \begin{array}{c}\text { J Jurusan Matematika FMIPA Untan, Pontianak } \\ \text { rimaliaa@ gmail.com }\end{array} \\ \text { YUNDARI } & \text { : Jurusan Matematika FMIPA Untan, Pontianak } \\ & \text { yundari@ @ath.untan.ac.id } \\ \text { YUDHI } & \text { Jurusan Matematika FMIPA Untan, Pontianak } \\ & \text { dhye_dhoank@yahoo.co.uk }\end{array}$

